\title{
IOT BASED SMART AGRO-INDUSTRIAL TECHNOLOGY WITH SPATIAL ANALYSIS
}

\section{TEKNOLOGI SMART AGROINDUSTRI BERBASIS IOT MENGGUNAKAN ANALISIS SPASIAL}

\author{
Rindra Yusianto $^{1)^{*}}$, Marimin $^{2)}$, Suprihatin ${ }^{2)}$, Hartrisari Hardjomidjojo ${ }^{2)}$ \\ ${ }^{1)}$ Program Studi Teknik Industri, Fakultas Teknik, Universitas Dian Nuswantoro \\ Jl. Nakula 1 No. 5-11 Semarang, Jawa Tengah, Indonesia \\ E-mail : rindra@staff.dinus.ac.id \\ ${ }^{2)}$ Department of Agro-industrial Engineering, Faculty of Agricultural Technology, IPB University \\ Makalah: Diterima 13 November 2020; Diperbaiki 18 Desember 2020; Disetujui 25 Desember 2020
}

\begin{abstract}
ABSTRAK
Smart teknologi berkembang pesat di sektor agroindustri. Tujuan dari penelitian ini adalah merancang dan mengembangkan sistem agroindustri kentang yang optimal dan adaptif. Dalam penelitian ini ditambahkan Internet of Things (IoT) yaitu penginderaan jauh untuk memprediksi jumlah panen dan kapasitas produksi. Sebelum menerapkan IoT, perspektif spasial dianalisis menggunakan spasial dan geoprocessing. Sampel penelitian menggunakan random grid di Wonosobo, Jawa Tengah, Indonesia. Titik optimal diperoleh di Kejajar $\left(N_{1}\right)$, Garung $\left(N_{2}\right)$, Kalikajar $\left(N_{3}\right)$, Kepil $\left(N_{4}\right)$ dan Mojotengah $\left(N_{5}\right)$. Pada penelitian ini dipasang sensor suhu dan kelembaban SHT15 serta curah hujan Rain Gauge di 5 titik. Sensor memberikan data secara rutin selama 30 hari. Berdasarkan analisis kesesuaian lahan, lokasi yang paling sesuai adalah Kejajar $\left(N_{1}\right)$ di koordinat $7^{\circ} 14^{\prime} 11.8^{\prime \prime} L S$, $109^{\circ} 56^{\prime 29.7 " B T . ~ H a s i l ~ p e n e l i t i a n ~ m e n u n j u k k a n ~ b a h w a ~ b e r d a s a r k a n ~} 24$ titik sampel dengan luas rata-rata 2,5mx $2,5 \mathrm{~m}$ dihasilkan rata-rata total panen $8,62 \mathrm{~kg} / \mathrm{m}^{2}$ dan prediksi produktivitas panen 13,79 ton/ha. Sistem ini dapat memprediksi jumlah panen dan kapasitas produksi yang baik dengan tingkat akurasi 89,35\%. Dengan demikian, metode ini dapat digunakan dan merepresentasikan pertanian melalui inovasi digital menggunakan smart teknologi agroindustri. Untuk penelitian selanjutnya, metode ini dapat dilanjutkan untuk penanganan pascapanen dengan menggunakan Sistem Operasi berbasis Android.
\end{abstract}

Kata kunci: agro-industrial technology, IoT, Smart technology, spatial analysis

\section{ABSTRACT}

Smart technology application is developing rapidly in the agro-industrial sectors. The objective of this research was to design and develop an optimal and adaptive system for post-harvest handling potatoes agroindustry. In this research, the Internet of Things (IoT) was added, namely the remote sensing to predict the harvest amount and production capacity. Before implementing IoT, the spatial perspective was analyzed using spatial analysis and geo-processing method. Research samples used a random grid based on Wonosobo, Central Java, Indonesia. The optimal point was obtained at Kejajar $\left(\mathrm{N}_{1}\right)$, Garung $\left(\mathrm{N}_{2}\right)$, Kalikajar $\left(\mathrm{N}_{3}\right)$, Kepil $\left(\mathrm{N}_{4}\right)$, and Mojotengah $\left(\mathrm{N}_{5}\right)$. In this research, SHT15 temperature and humidity sensors, and Rain Gauge rainfall were installed at 5 points. These sensors have provided data regularly per day for 30 days. Based on cropland suitability analysis, the most suitable location was Kejajar $\left(\mathrm{N}_{1}\right)$ at $7^{\circ} 14^{\prime} 11.8^{\prime \prime} \mathrm{S}, 109^{\circ} 56^{\prime} 29.7^{\prime \prime} \mathrm{E}$. The results showed that for 24 sample points of the size of $2.5 \mathrm{~m} \times 2.5 \mathrm{~m}$, the average harvest was $8.62 \mathrm{~kg} / \mathrm{m}^{2}$ and the predicted productivity was 13.79 ton/ha. The system could predict accurately the harvest amount and production capacity for an accuracy rate of $89.35 \%$. This method can be used and represents agriculture through digital innovation using smart agroindustrial technology. For future research, this method can be continued for post-harvest handling using Android Operating Systems.

Keywords: agro-industrial technology, IoT, smart technology, spatial analysis

\section{INTRODUCTION}

Currently, agricultural cropland can be selected based on its land suitability using precision agriculture (Seminar, 2016). Some of the technologies that have been developed are remote sensing and Geographic Information Systems (GIS) (Shanmugapriya et al., 2019). Both of these technologies provide solutions and convenience in continuous spatial analysis with a relatively wide coverage area (Nellis et al., 2008). The elaboration between remote sensing and GIS by considering a spatial perspective is expected to present smart agriculture through digital innovation.

The total harvest prediction of agro-industrial commodities is needed in planning, decision making, and strategic policy for food security (Septiani $e t a l$. 2016). One of commodities that needs special attention strategy is potatoes (Solanum tuberosum L). It is a commodity that has the potential and prospects to support diversification for achieving sustainable food security (Yusianto et al., 2019). Potatoes is the $4^{\text {th }}$ largest food agro-industrial commodity in Indonesia with is growing well in the environmental 
temperature of $15.6-18.3^{\circ} \mathrm{C}$, humidity of $80-90 \%$ and rainfall of $300 \mathrm{~mm} / \mathrm{month}$ (Voss et al., 2004; Sugiharyanto, 2017; Raja et al., 2020; Wang et al., 2020).

Based on data from the Indonesian Central Statistics Bureau in 2019, the 5 provinces with the most potato production are shown in Table 1. In Central Java, there are two potato producing districts with a harvest area of over 3,500 ha, namely Banjarnegara 124,484 ton and Wonosobo 54,265 (Table 2). Banjarnegara and Wonosobo districts, have several sub-districts with productivity above 15.0 ton/ha as can be seen in Table 3 .

Based on Table 3, Kejajar sub-district in Wonosobo has the highest productivity level, namely 15.44 tons/ha (Tabel 4) but is below the national potato productivity so the total harvest prediction and good post-harvest handling are needed (Kuyu et al., 2019; Yusianto et al., 2020).

The Internet of Things (IoT) platform can optimize the operation of precision agriculture (Marcu et al., 2019). IoT can be used to manage production, and optimize crop quality of agro- industrial commodities (Araby et al., 2019; Tervonen, 2018). The data is retrieved by remote sensing then entered into a machine learning algorithm. However, it did not discuss the type of sensor used. Antony et al. (2020) stated that precision agriculture supports with IoT and food security efforts has the potential to lead to independent agriculture. However, the study did not explain the IoT implementation. Performance evaluation and application of decision making to increase agro-industrial production requires a Decision Support System (DSS) (Marimin et al., 2017; Kardiyono et al., 2018; Yusianto et al., 2020).

An IoT-based DSS has been developed by Foughali et al. (2019). In their research, temperature, and climate data were collected using the IoT. They used the IoT Node MCU platform, the DHT11 humidity sensor, and a temperature sensor. Other research related to smart agriculture has been conducted by Kiani \& Seyyedabbasi (2018). The main objective of their research was to reduce water consumption while increasing agricultural productivity. However, this study did not discuss spatial analysis in the agro-industry.

Table 1. The largest potato producer in Indonesia

\begin{tabular}{|c|c|c|c|c|}
\hline \multirow{2}{*}{ Province } & \multicolumn{3}{|c|}{ Production per year (ton) } & \multirow{2}{*}{$\begin{array}{c}\text { Average } \\
\text { (tons) }\end{array}$} \\
\hline & 2016 & 2017 & 2018 & \\
\hline Central Java & 272,976 & 269,476 & 290,655 & 277,702 \\
\hline West Java & 288,368 & 277,187 & 265,536 & 277,030 \\
\hline East Java & 227,995 & 241,180 & 312,967 & 260,714 \\
\hline North Sumatra & 91,400 & 96,893 & 108,016 & 98,770 \\
\hline Jambi & 91,081 & 82,252 & 89,308 & 87,547 \\
\hline
\end{tabular}

Table 2. Potato production in Central Java, Indonesia

\begin{tabular}{lccc}
\hline District & $\begin{array}{c}\text { Production } \\
\text { (tons) }\end{array}$ & $\begin{array}{c}\text { Harvest area } \\
\text { (Ha) }\end{array}$ & $\begin{array}{c}\text { Productivity } \\
\text { (tons/Ha) }\end{array}$ \\
\hline Banjarnegara & 124,484 & 8,177 & 15.22 \\
Wonosobo & 54,265 & 3,511 & 15.46 \\
Brebes & 50,241 & 2,491 & 20.17 \\
Batang & 27,375 & 1,487 & 18.41 \\
Kab. Pekalongan & 11,742 & 618 & 19.00 \\
\hline
\end{tabular}

Table 3. Potato production in Banjarnegara and Wonosobo, Centra Java, Indonesia

\begin{tabular}{lccc}
\hline Sub-districts & $\begin{array}{c}\text { Production } \\
\text { (tons) }\end{array}$ & $\begin{array}{c}\text { Harvest area } \\
\text { (Ha) }\end{array}$ & $\begin{array}{c}\text { Productivity } \\
\text { (tons/Ha) }\end{array}$ \\
\hline Banjarnegara District & 124,484 & 8,177 & 15.22 \\
Batur & 78,975 & 5,137 & 15.37 \\
Pejawaran & 42,685 & 2,845 & 15.00 \\
Wanayasa & 2,456 & 163 & 15.07 \\
Kalibening & 368 & 32 & 11.50 \\
Wonosobo District & 54,265 & 3,511 & 15.46 \\
Kejajar & 44,610 & 2,890 & 15.44 \\
Kalikajar & 2,392 & 166 & 14.41 \\
\hline
\end{tabular}


Table 4. Existing conditions of potato production in Kejajar sub-district

\begin{tabular}{lc}
\hline Parameters & Existing condition \\
\hline Production (tons) & 44,610 \\
Harvested Area (Ha) & 2,890 \\
Productivity (ton/Ha) & 15.44 \\
\hline
\end{tabular}

Research on smart monitoring of potato crops has been conducted by Rad et al. (2015). They explained that the Cyber-Physical System (CPS) will play an important role in the agro-industry sector with precision agriculture. The CPS-based integrated system architecture is well described. However, this study did not include spatial analysis.

Most of the previous research has only discussed IoT and cloud computing implementations in precision agriculture. Discussion on spatial analysis by considering location coordinates (X, Y) and environmental factors, namely temperature, humidity, and rainfall was not obtained. In this research, the results of the spatial analysis were used as input for remote sensing, namely the determination of the harvest area and the prediction of the total harvest.

\section{RESEARCH AND METHODS}

In this research, a digital map of the location coordinates $(\mathrm{X}, \mathrm{Y})$ is processed through geoprocessing. The layer stacking result and geometric images determine cropland suitability. The intervals used were 3.75 and 4 classes.

\section{Research Framework}

Data collection using SHT15 temperature and humidity sensor with a single chip of a calibrated digital output (accuracy $\pm 0,4 @ 5-40^{\circ} \mathrm{C}$ ) with a 2.5 $\mathrm{V}$ power supply. The sensor will send data in *.dat extension form every one hour. The data was processed from the sensor into a temperature, humidity, and rainfall map. After determining the most suitable coordinate location, then the total harvest prediction is processed. This process requires data on the existing total harvest from each coordinate points, drone preparation, image processing, and image acquisition. The prediction results were then compared with the existing yields. The research framework can be seen in Figure 1.

The architectural system was designed into 2 main activities, namely cropland suitability, and total harvest prediction. The architectural system in predicting total harvest with IoT can be seen in Figure 2.

\section{Data Collection and Analysis}

Data were collected from 5 districts in Wonosobo, Central Java, Indonesia to determine an appropriate research sample. This study selected based on the largest number of productions. The spatial perspective was analyzed using spatial analysis. The spatial data were obtained from the Wonosobo Regional Development Planning Bureau. Meanwhile, geoprocessing uses a geo segregation analyzer. The research sample used a random grid based on Wonosobo administrative maps and spatial conditions. The sample node coordinates is shown in Figure 3.



Figure 1. Research framework 


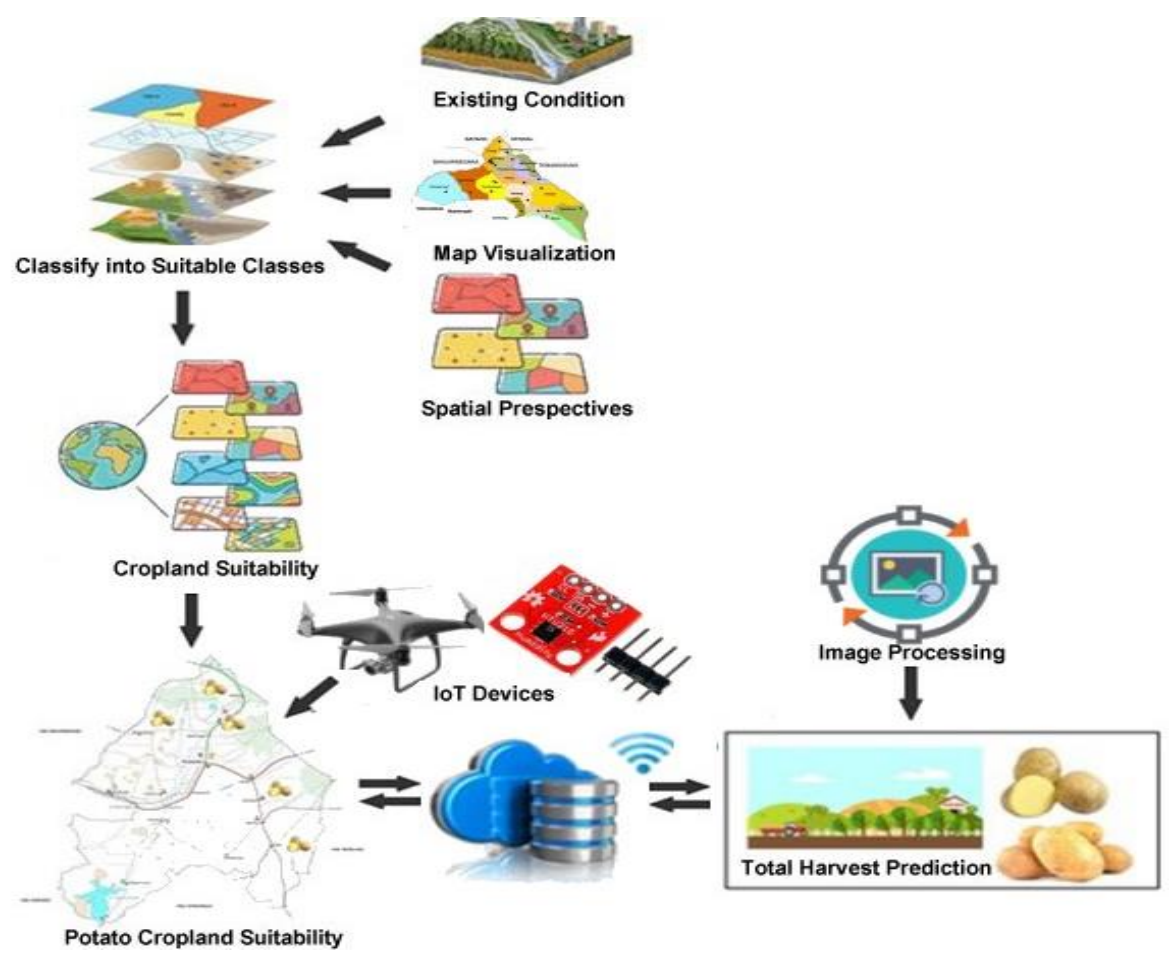

Figure 2. The system architecture

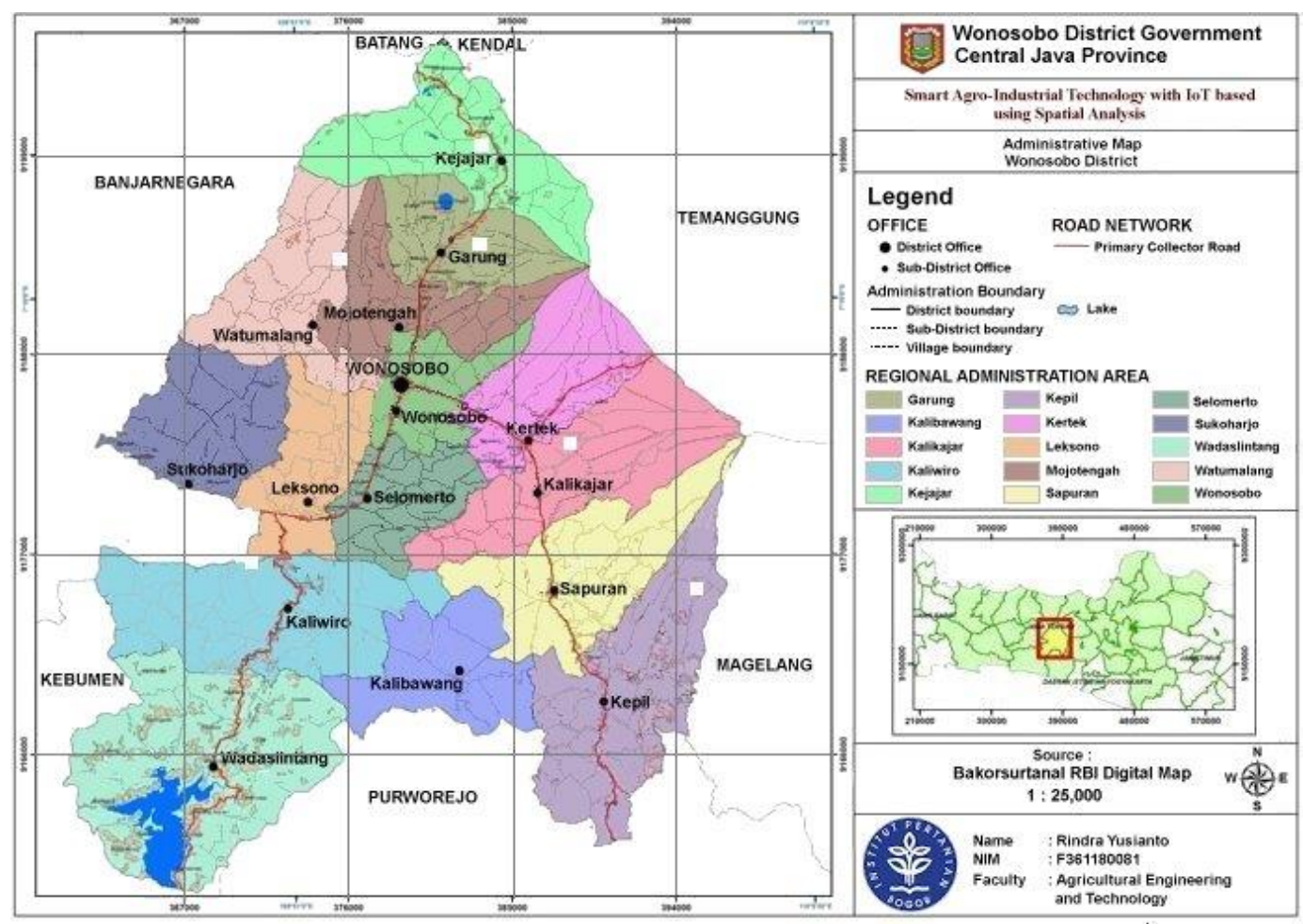

Figure 3. The sample node coordinate

Data recording was based on latitude $(\mathrm{X})$ and longitude (Y) coordinates. The node coordinates are shown in Table 5.

\section{Research variable}

The impact of climate change on cropland suitability is very important to sustainable agriculture
(Worqlul et al. 2019). Based on their research, Peter \& Messina (2020) proposed the factors that affect cropland suitability are temperature and rainfall. In addition, Tesfay et al. (2017) found the slope profile, soil type, and moisture are also important factor of cropland suitability. 
Table 5. The sample nodes coordinates

\begin{tabular}{lcccc}
\hline Location & Id & $\begin{array}{c}\text { Latitude } \\
(\mathbf{X})\end{array}$ & $\begin{array}{c}\text { Longitude } \\
(\mathbf{Y})\end{array}$ & $\begin{array}{c}\text { Existing production } \\
\text { (tons) }\end{array}$ \\
\hline Tieng, Kejajar & $\mathrm{N}_{1}$ & $7^{\circ} 14^{\prime} 11.8^{\prime \prime} \mathrm{S}$ & $109^{\circ} 56^{\prime} 29.7^{\prime \prime} \mathrm{E}$ & 447,060 \\
Jengkol, Garung & $\mathrm{N}_{2}$ & $7^{\circ} 16^{\prime} 52.1^{\prime \prime} \mathrm{S}$ & $109^{\circ} 56^{\prime} 37.2^{\prime \prime} \mathrm{E}$ & 74,240 \\
Tegalombo, Kalikajar & $\mathrm{N}_{3}$ & $7^{\circ} 22^{\prime} 38.5^{\prime \prime} \mathrm{S}$ & $109^{\circ} 59^{\prime} 33.6^{\prime \prime} \mathrm{E}$ & 19,683 \\
Ropoh, Kepil & $\mathrm{N}_{4}$ & $7^{\circ} 27^{\prime} 40.6^{\prime \prime} \mathrm{S}$ & $110^{\circ} 02^{\prime} 44.9^{\prime \prime} \mathrm{E}$ & 1,031 \\
Deroduwur, Mojotengah & $\mathrm{N}_{5}$ & $7^{\circ} 17^{\prime} 31.6^{\prime \prime} \mathrm{S}$ & $109^{\circ} 52^{\prime} 31.7^{\prime \prime} \mathrm{E}$ & 905 \\
\hline
\end{tabular}

In this research, land suitability was measured by the variables of temperature, humidity, and rainfall. To determine suitable cropland, the class was divided into four classes which are very good at a score of 4 , good 3, moderate 2, and bad 1. The variables of temperature, humidity, and rainfall were analyzed as follows:

\section{Temperature}

Temperature affects production, the extent of potato damages when harvested, and post-harvest weight loss (Voss et al., 2004). The most suitable temperature for growing potatoes is $17.4-20.0^{\circ} \mathrm{C}$. Based on the Rykaczewska (2017) study, in this research, the temperature was classified as in Table 6.

Table 6. Temperature classes and criteria

\begin{tabular}{lcc}
\hline Classes & Temperature $\left({ }^{\mathbf{0}} \mathbf{C}\right)$ & Value \\
\hline Very Good & $15.6-17.8$ & 4 \\
Good & $17.7-20.0$ & 3 \\
Moderate & $20.1-30.0$ & 2 \\
Bad & $>30.0$ & 1 \\
\hline
\end{tabular}

\section{Humidity}

Potato plants will grow best in the area with the humidity of between $80-90 \%$ (Backhausen et al., 2005; Sugiharyanto, 2017). Humidity classes and their criteria value in this research can be seen in Table 7.

Table 7. Humidity classes and criteria

\begin{tabular}{lcc}
\hline Classes & Humidity $(\boldsymbol{\%})$ & Value \\
\hline Very Good & $>89$ & 4 \\
Good & $80-89$ & 3 \\
Moderate & $70-79$ & 2 \\
Bad & $<70$ & 1 \\
\hline
\end{tabular}

\section{Rainfall}

Rainfall affects potato growth and the consistency of production. Rainfall that is too high can leached-out the nutrients needed for potato growth (Zeyayen et al., 2017; Shimoda et al., 2018; Hou et al., 2020). Average rainfall classes and their criteria in this research can be seen in Table 8 .

The prediction was made by the predicted optimal total harvest of the most suitable land. The difference was calculated between the highest-grade total scores $\left(\mathrm{V}_{\mathrm{n}}\right)$ and the lowest total class value $\left(\mathrm{V}_{1}\right)$, then divided by the number of classes created (C). In this research, intervals of 3.00 and 4 classes used as shown in Table 9

Table 8. Average rainfall classes and criteria

\begin{tabular}{lcc}
\hline Classes & Rainfall $(\mathbf{m m} / \mathbf{m o n t h})$ & Value \\
\hline Very Good & $>300$ & 4 \\
Good & $200-300$ & 3 \\
Moderate & $60-200$ & 2 \\
Bad & $<60$ & 1 \\
\hline
\end{tabular}

Table 9. Cropland suitability level interval

\begin{tabular}{ccl}
\hline Class & Total value & $\begin{array}{c}\text { Cropland suitability } \\
\text { level }\end{array}$ \\
\hline $\mathrm{S}_{1}$ & $>12.2$ & The most suitable \\
$\mathrm{S}_{2}$ & $9.2-12.2$ & Suitable \\
$\mathrm{S}_{3}$ & $6.1-9.1$ & Rather suitable \\
$\mathrm{NS}$ & $2.0-6.0$ & Unsuitable \\
\hline
\end{tabular}

SHT15 sensors were installed at five points. The sensor provides data periodically per day for 30 days and processed manually, so that the average temperature, humidity, and rainfall data were obtained as in Table 10 .

The average temperature were above $20^{\circ} \mathrm{C}$ except at the sample point $\mathrm{N}_{1}$ which was around $19^{\circ} \mathrm{C}$. The average rainfall were above $300 \mathrm{~mm} / \mathrm{month}$ or higher than $3,000 \mathrm{~mm} /$ year with the smallest rainfall at sample point $\mathrm{N}_{5}$, namely $317.75 \mathrm{~mm} /$ month.

\section{Research Methods}

The cropland was mapped to a size of $2.5 \times 2.5$ $\mathrm{m}^{2}$ using a rope. Image processing using the multi thresholding method. This method was used to separate an image into several regions based on the pixel intensity value that has previously been converted into a greyscale form. Two segmentations were used to distinguish leaves and background objects. The segmentation results were calculated based on the percentage of the pixel segmentation. Image acquisition data generated were grouped into 24 blocks and labeled from block A1 to block F4. The acquired image was segmented using multithresholding. The image was converted into a greyscale form by extracting the yellow component from the original image. 
Table 10. Value of temperature, humidity, and rainfall

\begin{tabular}{ccccccc}
\hline \multirow{2}{*}{$\begin{array}{c}\text { Sample } \\
\text { code }\end{array}$} & \multicolumn{2}{c}{ Temperature } & \multicolumn{2}{c}{ Humidity } & \multicolumn{2}{c}{ Rainfall } \\
\cline { 2 - 7 } & ${ }^{\mathbf{0}} \mathbf{C}$ & Value & \% & Value & mm/ month & Value \\
\hline $\mathrm{N}_{1}$ & 19 & 3 & $90-95$ & 4 & 341.00 & 4 \\
$\mathrm{~N}_{2}$ & 23 & 2 & $80-90$ & 3 & 326.83 & 4 \\
$\mathrm{~N}_{3}$ & 23 & 2 & $80-90$ & 3 & 351.92 & 4 \\
$\mathrm{~N}_{4}$ & 27 & 2 & $80-90$ & 3 & 347.08 & 4 \\
$\mathrm{~N}_{5}$ & 24 & 2 & $80-90$ & 3 & 317.75 & 4 \\
\hline
\end{tabular}

Table 11. Cropland suitability classification

\begin{tabular}{clcl}
\hline $\begin{array}{c}\text { Sample } \\
\text { code }\end{array}$ & \multicolumn{1}{c}{ Location } & Result \\
\cline { 3 - 4 } $\mathrm{N}_{1}$ & Tieng, Kejajar & 11 & Suitable \\
$\mathrm{N}_{2}$ & Jengkol, Garung & 9 & Rather Suitable \\
$\mathrm{N}_{3}$ & Tegalombo, Kalikajar & 9 & Rather Suitable \\
$\mathrm{N}_{4}$ & Ropoh, Kepil & 9 & Rather Suitable \\
$\mathrm{N}_{5}$ & Deroduwur, Mojotengah & 9 & Rather Suitable \\
\hline
\end{tabular}

Equation (1) was used to calculate the accuracy rate for predicting the total harvest.

Accuracy rate $=\frac{\text { The total harvest prediction }}{\text { Existing condition }} \times 100 \%$.

Where the total harvest prediction was obtained using Equation (2).

The total harvest prediction $=$ Prediction of production capacity Total sample area

\section{RESULT AND DISCUSSION}

This section discusses spatial analysis, system implementation, image acquisition result, research limitation, and managerial implications.

\section{Spatial Analysis}

Based on cropland suitability level intervals, cropland suitability classes can be seen in Table 11 . The spatial analysis produces X, Y coordinates. The map was divided into 16 grids with each distance of $1.5 \mathrm{~km}$. Figure 4 shows that the points in the northern part have suitable land criteria, while the middle, eastern and western parts have moderate criteria. The figure also depicts spatial distribution of potato land suitability.

\section{System Implementation}

Based on cropland suitability, Kejajar subdistrict has good land that is expected to reach the maximum total harvest. The map of Kejajar subdistrict can be seen in Figure 5 .

\section{Images Acquisition Results}

The drone used in this study is the DJI quadcopter drone. The flight area was registered for the drone deploys application of the smartphone. The area registration is determined by the flying height, overlap, the photo-taking direction, and the shooting area. After the setup has been completed, the map of the captured image was ready to degenerate. Image acquisition was carried out just before harvest, which was 90 days after planting. Mapping land measuring $2.5 \times 2.5 \mathrm{~m}^{2}$ using a rope. The drone was flown at an altitude of $4 \mathrm{~m}$. Image processing is done using the multi thresholding method

This method is used to separate an image into several regions based on the pixel intensity value that has previously been converted into a greyscale form. This study, using 2 segmentations to distinguish leaves and background objects. The segmentation results are calculated based on the percentage of the pixel segmentation. Image acquisition data generated are grouped into 24 blocks and labeled wirh block A1 to block F4.

The acquired image was segmented using multi-thresholding. The image was converted into a greyscale form by extracting the yellow component from the original image as shown in Figure 7.

The separation of regions using multithresholding was then displayed in the segmentation results. Where region 1 is the background image, and region 2 was the potato leaf image. After processing the pixel percentage data for each region, the harvest samples were weighed. The average sample weight was $8.62 \mathrm{~kg}$ or has productivity of $1.38 \mathrm{~kg} / \mathrm{m}^{2}(13.79$ tons/ha) (Table 12). 


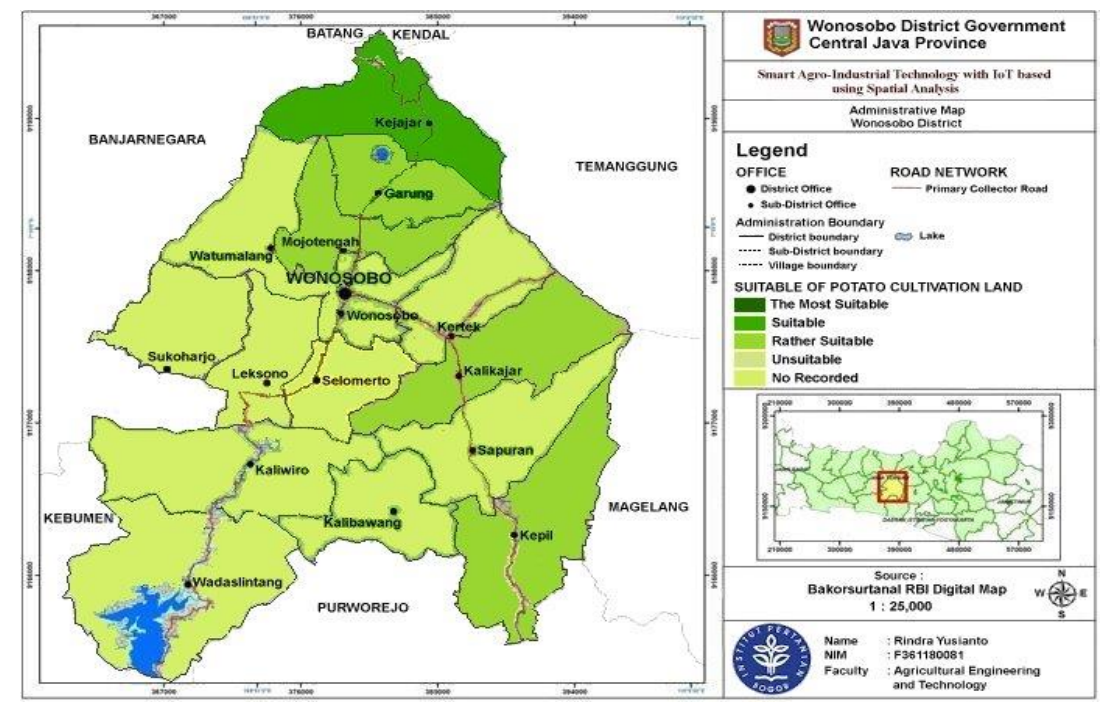

Figure 4. Spatial distribution cropland suitability

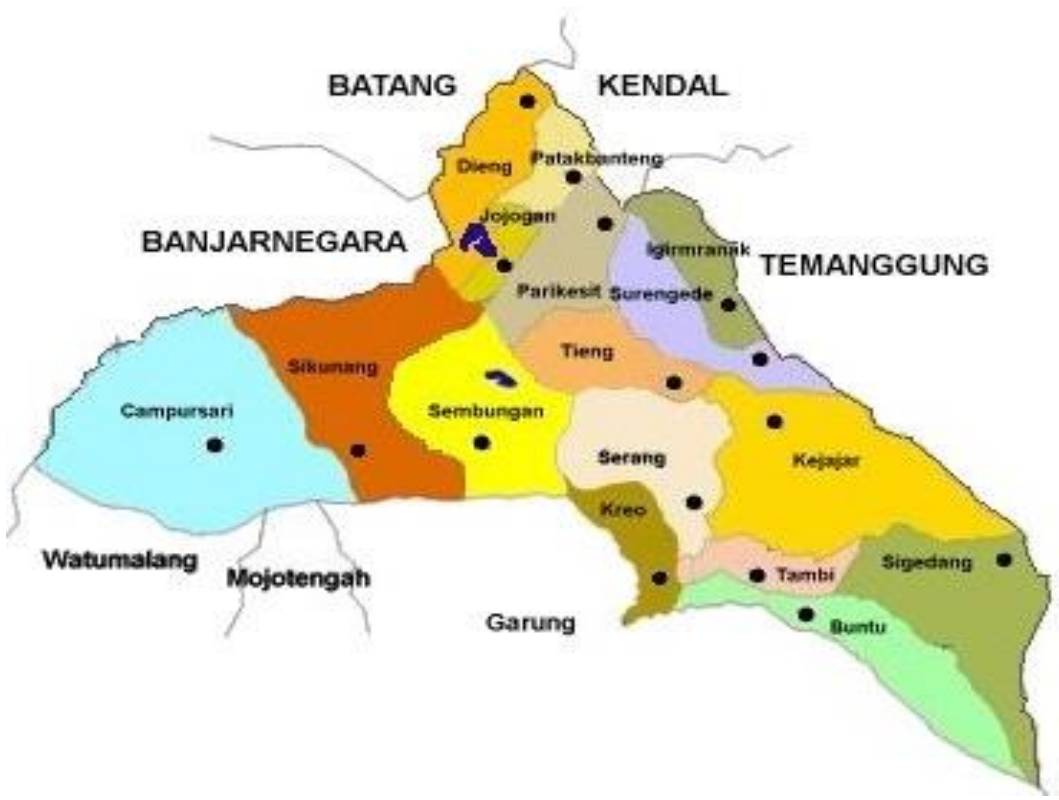

*) the colors in this figure only show the boundaries of the area

Figure 5. Kejajar sub-district map*


Figure 6. Image acquisition 


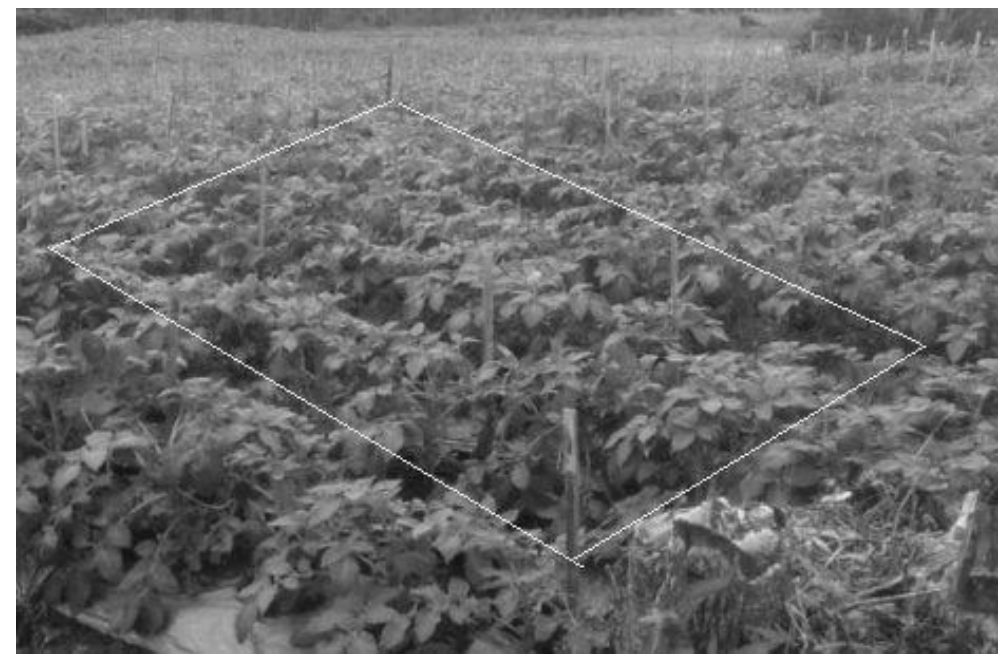

Figure 7. Acquisition image in the grayscale form

Table 12. The result of weighing harvest data

\begin{tabular}{cccc}
\hline Block & Weight $(\mathbf{K g})$ & Block & Weight $(\mathbf{K g})$ \\
\hline A1 & 8.50 & D1 & 9.89 \\
A2 & 9.67 & D2 & 9.96 \\
A3 & 8.20 & D3 & 8.10 \\
A4 & 8.98 & D4 & 9.87 \\
B1 & 7.70 & E1 & 9.50 \\
B2 & 7.30 & E2 & 10.10 \\
B3 & 8.20 & E3 & 9.78 \\
B4 & 10.50 & E4 & 8.10 \\
C1 & 8.90 & F1 & 7.20 \\
C2 & 7.98 & F2 & 7.25 \\
C3 & 7.20 & F3 & 7.00 \\
C4 & 7.05 & F4 & 9.96 \\
\hline
\end{tabular}

\section{Discussion}

Based on 24 sample points with an average area of $2.5 \mathrm{~m} \times 2.5 \mathrm{~m}$, the average total harvest was $8.62 \mathrm{~kg}$ per $\mathrm{m}^{2}$. A comparison of existing conditions with predictions using IoT and spatial analysis can be seen in Table 13.

Table 13. The total harvest comparison

\begin{tabular}{lcc}
\hline \multicolumn{1}{c}{ Comparison } & $\begin{array}{c}\text { Existing } \\
\text { condition }\end{array}$ & $\begin{array}{c}\text { Prediction of the } \\
\text { total harvest }\end{array}$ \\
\hline $\begin{array}{l}\text { Production } \\
\text { (tons) }\end{array}$ & 44,610 & 8.62 \\
$\begin{array}{l}\text { Harvested Area } \\
\text { (Ha) }\end{array}$ & 2,890 & 0.63 \\
$\begin{array}{l}\text { Productivity } \\
\text { (tons/Ha) }\end{array}$ & 15.44 & 13.79 \\
\hline
\end{tabular}

Based on Table 13, the system can provide predictions of the total harvests with an accuracy rate of $89.35 \%$. This level of accuracy of a developed systems with the IoT framework can be categorized as optimal, adaptive, and flexible According to (Foughali et al. 2018). Liu et al. (2020) in their study of Hybrid Rice Optimization (HRO) using a multithresholding approach, more accurate predictions can be made, especially regarding the food safety situation.

The Web Ontology Language (WOL) pattern in the semantic web using spatial-temporal variables, as well as interpolation and aggregation procedures on spatial statistics, can further improve the accuracy of predictions (Stasch et al., 2014). Intelligent Spatial System combined with DSS can predict more accurately harvest time, waiting time, and optimal route determination in the agro-industrial sector (Yusianto et al., 2019). The accuracy obtained in this study, according to Dewi \& Muslikh (2013), is good since it was higher than $80 \%$. This research has approved that an IoT based smart agro-industrial technology and spatial analysis can predict harvest volume and productivity with a better accuracy rate. 


\section{Research Limitations}

This method can assist decision-makers in determining the most suitable cropland. Using the IoT framework, namely SHT15 and the Rain Gauge sensor at five points coordinates by considering the spatial perspective, has been able to increase the level of accuracy in predicting total harvest and production capacity.

In this research, sample collection was carried out during one harvest period. With this limitation, sampling was done randomly. The 24-point samples were not validated. Mined data was processed manually using the SHT15 sensor. The data sent was then stored on the chip periodically to obtain the average temperature, humidity, and rainfall. A GUI application to manipulate the SHT15 sensor data mining in real-time has not been made.

\section{Managerial Implications}

The prediction of total harvest is one of the obstacles in the agricultural production. By being able to predict the total harvest in the future, decisionmakers can quickly, precisely, and accurately take necessary policies related to production and postharvest handling, including balancing the supply and demand.

\section{CONCLUSIONS AND RECOMMENDATIONS}

\section{Conclusions}

Based on cropland suitability analysis, the most suitable location is Kejajar sub-district at $7^{\circ} 14^{\prime} 11.8^{\prime \prime} \mathrm{S}, 109^{\circ} 56^{\prime} 29.7^{\prime \prime} \mathrm{E}$. The results showed that implementation of the model was useful in the agroindustry, especially in the early stages of post-harvest handling. The system can run optimally, and adapted to post-harvest handling of potatoes agro-industry. The system can provide predictions of the harvest volume and productivity the accuracy rate of $89.35 \%$. This means the method can be used and representing agriculture through digital innovation using smart agro-industrial technology.

\section{Recommendations}

The SHT15 and the Rain Gauge sensor was installed at 5 coordinate points. The sensor provided data periodically per day for 30 days and processed manually, so that the average temperature, humidity, and rainfall were obtained. For future research, this method can be continued for post-harvest logistics handling using Android Operating Systems. Where data mining can be integrated into Android-based applications automatically.

\section{REFERENCES}

Antony AP, Leith K, Jolley C, Lu J, Sweeney DJ. 2020. A review of practice and implementation of the internet of things (IoT) for smallholder agriculture. Sustainability. 12(9):1-19.
Araby AA, Abd Elhameed MM, Magdy NM, Said LA, Abdelaal N, Abd Allah YT, Darweesh MS, Fahim MA, Mostafa H. 2019. Smart IoT Monitoring System for Agriculture with Predictive Analysis. Proceedings of 8th International Conference on Modern Circuits and Systems Technologies, Thessaloniki, Greece. 13-15 May 2019.

Backhausen JE, Klein M, Klocke M, Jung S, Scheibe R. 2005. Salt tolerance of potato (Solanum tuberosum L . var . Desire) plants depends on light intensity and air humidity. Plant Science. 169(1): 229-237.

Dewi C and Muslikh M. 2013. Perbandingan Akurasi Backpropagation Neural Network dan ANFIS Untuk Memprediksi Cuaca. Journal of Scientific Modeling \& Computation. 1(1): 7-13.

Foughali K, Fathallah K, and Frihida A. 2019. A Cloud-iot based decision support system for potato. Procedia Computer Science. 160(1): 616-623.

Foughali K, Fathallah K, and Frihida A. 2018. Using Cloud IOT for disease prevention in precision agriculture. Procedia Computer Science. 130(1): 575-582.

Hou X, Li R, He W, Ma K. 2020. Effects of planting density on potato growth, yield, and water use efficiency during years with variable rainfall on the Loess Plateau, China. Agricultural Water Management. 230(11): 1-9.

Kardiyono, Marimin, Indastri NS, Yuliasih I, Pramuhadi G. 2018. Strategi peningkatan produktivitas dan kualitas kedelai lokal dengan pendekatan produktivitas hijau. Jurnal Teknologi Industri Pertanian. 28(3): 342-353.

Kiani F and Seyyedabbasi A. 2018. Wireless sensor network and Internet of Things in precision agriculture. International Journal of Advanced Computer Science and Applications. 9(6): 99103.

Kuyu CG, Tola YB, and Abdi GG. 2019. Study on post-harvest quantitative and qualitative losses of potato tubers from two different road access districts of Jimma zone, South West Ethiopia. Heliyon. 5(7): 1-7.

Liu W, Huang Y, Ye Z, Cai W, Yang S, Cheng X. 2020. Renyi's Entropy Based Multilevel Thresholding Using a Novel Meta-Heuristics Algorithm. Applied Sciences. 10(1): 1-18.

Marcu I, Voicu C, Dragulinescu AMC, Fratu O, Suciu G, Balaceanu C, Andronache MM. 2019. Overview of IoT basic platforms for precision agriculture. Lecture Notes of the Institute for Computer Sciences, Social-Informatics and Telecommunications Engineering. 283(3): 124137.

Marimin, Adhi W, and Darmawan MA. 2017. Decision support system for natural rubber supply chain management performance measurement: A sustainable balanced 
scorecard approach. International Journal of Supply Chain Management. 6(2): 60-74.

Nellis MD, Price KP, and Rundquist D. 2008. Remote Sensing of Cropland Agriculture. In The SAGE Handbook of Remote Sensing. University of Nebraska - Lincoln. pp. 368-383.

Peter BG and Messina JP. 2020. Crop climate suitability mapping on the cloud: a geovisualization application for sustainable agriculture. Scientific Reports:1-17.

Rad C-R, Hancu O, Takacs I-A, Olteanu G. 2015. Smart Monitoring of Potato Crop: A CyberPhysical System Architecture Model in the Field of Precision Agriculture. Agriculture and Agricultural Science Procedia. 6(1): 73-79.

Raja S, Govindakrishnan P, and Chakrabarti S. 2020. A Review: A Framework for Yield Improvement in Kharif/Rainy Season Potato in the Low Land Tropics. Acta Horticulturae et Regiotecturae. 23(1): 44-55.

Rykaczewska K. 2017. Impact of heat and drought stresses on size and quality of the potato yield. Plant Soil Environment. 63(1): 40-46.

Seminar KB. 2016. Sistem Pertanian Presisi dan Sistem Pelacakan Rantai Produksi untuk Mewujudkan Agroindustri Berkelanjutan. Orasi Ilmiah Guru Besar Tetap Fakultas Teknologi Pertanian Institut Pertanian Bogor (November).

Septiani W, Marimin, Herdiyeni Y, Haditjaroko L. 2016. Method and Approach Mapping for Agrifood Supply Chain Risk Management: A literature review. International Journal of Supply Chain Management. 5(2): 51-64.

Shanmugapriya P, Rathika S, Ramesh T, Janaki P. 2019. Applications of Remote Sensing in Agriculture - A Review. International Journal of Current Microbiology and Applied Sciences. 8(01): 2270-2283.

Shimoda S, Kanno H, and Hirota T. 2018. Agricultural and Forest Meteorology Time series analysis of temperature and rainfallbased weather aggregation reveals signi fi cant correlations between climate turning points and potato (Solanum tuberosum $L$ ) yield trends in Japan. Agricultural and Forest Meteorology. 263(8):147-155.

Stasch C, Scheider S, Pebesma E, Kuhn W. 2014. Meaningful spatial prediction and aggregation.
Environmental Modelling and Software. 51(1): 149-165.

Sugiharyanto S. 2017. Prospek Pengembangan Budidaya Tanaman Kentang di Indonesia. Geomedia: Majalah Ilmiah dan Informasi Kegeografian. 6(2): 43-52.

Tervonen J. 2018. Experiment of the quality control of vegetable storage based on the Internet-ofThings. Procedia Computer Science. 130: 440447.

Tesfay T, Biedemariam M, Hagazi M, Hailu TG. 2017. Land Capability and Suitability Evaluation for Rain-fed Crops in Semi-arid Lowland Area of North. An International Journal of Plant Research. 30(3): 1-5.

Voss RE, Baghott KG, and Timm H. 2004. Proper Environment for Potato Storage. Vegetable Research and Information Center. 3(1): 1-3.

Wang Y, Naber MR, and Crosby TW. 2020. Effects of wound-healing management on potato postharvest storability. Agronomy. 10(4): 1-17.

Worqlul AW, Dile YT, Jeong J, Adimassu Z, Lefore N, Gerik T, Srinivasan R, Clarke N. 2019. Original papers $\mathrm{E}$ ff ect of climate change on land suitability for surface irrigation and irrigation potential of the shallow groundwater in Ghana. Computers and Electronics in Agriculture. 157(8): 110-125.

Yusianto R, Marimin, Suprihatin, Hardjomidjojo H. 2019. Intelligent Spatial Logistics DSS for tracking and tracing in horticultural food security. Proceedins of International Seminar on Application for Technology of Information and Communication (iSemantic). Semarang, Indonesia. 21-22 September 2019.

Yusianto R, Marimin, Suprihatin, Hardjomodjojo H. 2020. Spatial Analysis for Crop Land Suitability Evaluation: A Case Study of Potatoes Cultivation in Wonosobo, Indonesia. Proceedins of International Seminar on Application for Technology of Information and Communication (iSemantic). Semarang, Indonesia. 19-20 September 2020.

Zeyayen S, Fattahi E, Ranjbar A, Vazifedoust M. 2017. Classification of rainfall warnings based on the TOPSIS method. Climate. 5(33):1-12. 